\title{
32. PALEOMAGNETIC ANALYSES OF SHORT NORMAL POLARITY MAGNETIC ANOMALIES IN THE MATUYAMA CHRON ${ }^{1}$
}

\author{
Yves Gallet, ${ }^{2,3}$ Jeff Gee, ${ }^{3}$ Lisa Tauxe,${ }^{3}$ and John A. Tarduno ${ }^{3}$
}

\begin{abstract}
We document three short normal intervals in the natural remanent magnetization of sediments within the Matuyama Chron. These three anomalous zones of magnetization between the Jaramillo and Olduvai subchrons were identified from continuous measurements of archive halves from Hole $803 \mathrm{~A}$ using the pass-through $2 \mathrm{G}$ cryogenic magnetometer at Scripps. The U-channel samples were taken from the three intervals, analyzed using the pass-through system, and then cut into discrete 1-cm-thick samples. Measurements on discrete samples confirmed the presence of the upper normal polarity zone. Based on sedimentation rate calculations, this zone is confidently correlated with the Cobb Mountain Subchron. For the two other anomalous zones, complete thermal demagnetization revealed a high-stability component $\left(250^{\circ}-575^{\circ} \mathrm{C}\right)$ of reversed polarity. The intensity of the low-stability normal polarity component, normalized by susceptibility, remains roughly constant throughout the entire interval sampled, whereas the intensity of the high-stability reversed component is much lower within the normal zone than outside. We interpret these two normal zones, then, as periods of low (reversed polarity) geomagnetic field intensity resulting in low magnetization of the sediments; the periods of these low magnetization reversed polarity zones are completely masked by the component acquired viscously in a normal polarity field.
\end{abstract}

\section{INTRODUCTION}

Most of the information we have about the chronology of magnetic reversals for the Cenozoic and the latter part of the Mesozoic comes from the patterns of magnetic anomalies over the seafloor. A large number of magnetostratigraphic studies, on land sections or on deepsea sediments, have corroborated these patterns and have been used to tie the oceanic magnetic anomaly sequence to geologic stages. Ultimately, successive improvements of the sequence have culminated in a continuous record of the geomagnetic polarity spanning about 160 m.y. (see Harland et al., 1989, and Lowrie, 1989, for reviews). However, from the beginning of the development of the magnetic time scale, many authors have suggested the existence of "forgotten" short magnetic intervals (e.g., Watkins, 1968; Blakely and Cox, 1972; Blakely, 1974; Champion et al., 1988). In marine geophysics, the problem of detection of polarity intervals of short duration (i.e., shorter than about 40 k.y.), arises from the limited time resolution provided by standard oceanographic surveys (LaBrecque et al., 1977).

In magnetostratigraphy, resolution is limited by aspects of the sedimentary record such as the completeness of the studied section, the sedimentation rate within a section, and/or the sampling density. In addition, the sequence of magnetization components within sedimentary rocks must be understood to ensure that the isolated directions are primary. After $20 \mathrm{yr}$ of investigation, the existence of short polarity intervals is still a matter of debate. Assuming a Poissonian distribution for geomagnetic reversals, McFadden and Merrill (1984) suggested that about $40 \%$ of the observed intervals in the geomagnetic reversal time scale could be the result of the concatenation of one or several shorter intervals. This analysis suggests that about 80 polarity intervals would be missing since the end of the Cretaceous long normal interval. Based on marine magnetic anomaly records, LaBrecque et al. (1977) identified 57 small wave-length features in the Paleogene that may represent short polarity intervals. They can be

\footnotetext{
'Berger, W.H., Kroenke, L.W., Mayer, L.A., et al., 1993. Proc. ODP, Sci. Results, 130: College Station, TX (Ocean Drilling Program).

${ }^{2}$ Laboratoire de Paléomagnétisme et Géodynamique, Institut de Physique du Globe de Paris, 4 place Jussieu, 75252 Paris Cedex 05, France.

${ }^{3}$ Geological Research Division, Scripps Institution of Oceanography, University of California, San Diego, La Jolla, CA 92093, U.S.A.
}

modeled as full reversals or intensity fluctuations of the dipole field equally well. Moreover, the majority of these intervals are of normal polarity and could represent contamination by present field overprints rather than true polarity reversals (Cande and LaBrecque, 1974; Lowrie and Kent, 1983).

Numerous detailed magnetostratigraphic studies, from volcanic rocks and from marine or terrestrial sediments, have focused on the magnetic polarity sequence of the last $5 \mathrm{~m}$.y. Despite the large number of studies, many details remain uncertain concerning the age of the recent magnetic reversals and the exact signature of the magnetic sequence. Recently, Champion et al. (1988) proposed a tentative chronology of eight reversed subchrons, roughly evenly spaced within the Brunhes Normal Chron. The existence of some of these features is dubious, and it is beyond the scope of this paper to review the evidence for these short events. However, at least one of them, the Blake Subchron at about 1.2 k.y. (Smith and Foster, 1969; Denham, 1976), is well documented in sedimentary sections (e.g., Denham, 1976; Creer et al., 1980; Tucholka et al., 1987; Tric et al., 1991).

Several short normal polarity intervals have also been reported within the Matuyama Chron (e.g., Watkins, 1968; McDougall and Watkins, 1973; Kent and Spariosu, 1982; Clement and Kent, 1987). The Réunion Subchron, at about 2 Ma (just older than the Olduvai Subchron), was originally recognized in oceanic magnetic profiles (as a very small but persistent anomaly called " $X$ " by Heirtzler et al., 1968) and from basalt lava flows on Réunion Island (McDougall and Watkins, 1973). Magnetostratigraphic studies from oceanic sediments recovered from DSDP-ODP drilling often show some evidence for the Réunion interval (e.g., Tauxe et al., 1989), but no detailed magnetostratigraphic record of this subchron is presently available. In contrast, Clement and Kent (1987) provided a detailed record, from sediments cored in the North Atlantic (Site 609, Leg 94), of two other magnetic features of normal polarity between the Olduvai and Jaramillo subchrons. The more recent one, the Cobb Mountain Subchron, was first recognized by paleomagnetic study of oceanic sediments (e.g., Watkins, 1968). It has also been observed from basalt flows (Mankinen et al., 1978; Mankinen and Grommé, 1982; Chauvin et al., 1990). K/Ar radiometric analyses (Mankinen et al., 1978; Duffield et al., 1980; Chauvin et al., 1990) give an age of about 1.12 m.y. for this subchron. An extrapolated age of about $1.55 \mathrm{Ma}$ can be derived for the older interval, called the Gilsa Event. The presence of a normal interval just younger than the Olduvai 
Subchron has frequently been the subject of discussion (e.g., Cox, 1969; Emilia and Heinrichs, 1969; Grommé and Hay, 1971; Watkins et al., 1975; Mankinen and Dalrymple, 1979). The record obtained by Clement and Kent (1987) shows a clear discrete interval, although full polarity directions were observed only in $3 \mathrm{~cm}$ of the stratigraphic section. For this reason, Clement and Kent (1987) interpreted this interval as a geomagnetic excursion rather than a subchron.

Parallel with the observation of short polarity intervals, the question of the worldwide occurrence of these intervals is also under discussion. In other words, this is a problem of differentiation between a magnetic excursion (geographically limited in space) and a true (worldwide) magnetic reversal. The way to solve this problem in a specific case is to provide several records of the same interval from different areas and to test whether the magnetic directions observed within the interval are fully antipodal to those observed outside the interval.

In this paper, we report initial paleomagnetic results obtained from sediments of three dedicated holes drilled during Ocean Drilling Program (ODP) Leg 130 on the Ontong Java Plateau, in the western equatorial Pacific. The area investigated during Leg 130 is located on the northeastern margin of the Ontong Java Plateau. This submarine plateau occupies a broad area $(>1000 \times 1500 \mathrm{~km})$ and is one of the largest oceanic plateaus. A thick (ca. 1000-1500 m) sedimentary sequence, spanning the Cenozoic and late Mesozoic, overlies the shallowest portions of the plateau. New paleontologic data (from Leg 130) indicate an Early Aptian age for the oldest sediments overlying the basalt (Tarduno et al., 1991b). Paleomagnetic analyses of basalt, which include one flood basalt unit, show only normal magnetic polarity and may indicate formation of the plateau at the beginning of the Cretaceous Normal Polarity Superchron (Tarduno et al., 1991b). Analogous to the Deccan Traps volcanism (Courtillot et al., 1986; Vandamme et al., 1991), Tarduno et al. (1991b) have suggested that construction of the Ontong Java Plateau is related to a large mantle plume.

During Leg 130, five sites were cored with the advanced hydraulic piston corer (APC) (Sites 803-807), and three of these (Sites 803, 805 , and 806) included dedicated holes for paleomagnetic study. All three dedicated holes sampled Pliocene to Pleistocene nannofossil ooze: $58 \mathrm{~m}$ at Hole $803 \mathrm{~A}\left(2.4^{\circ} \mathrm{N}, 160.5^{\circ} \mathrm{E}\right.$; water depth $\left.3410 \mathrm{~m}\right), 52 \mathrm{~m}$ at Hole $805 \mathrm{~A}\left(1.2^{\circ} \mathrm{N}, 160.5^{\circ} \mathrm{E}\right.$; water depth $\left.3189 \mathrm{~m}\right)$, and an $86-\mathrm{m}$ section at Hole $806 \mathrm{~A}\left(0.3^{\circ} \mathrm{N}, 159.0^{\circ} \mathrm{E}\right.$; water depth $\left.2521 \mathrm{~m}\right)$. Shipboard paleomagnetic and paleontologic measurements indicate sedimentation rates of $1-1.5 \mathrm{~cm} / \mathrm{k} . \mathrm{y}$. for Site 803 , about $1.7 \mathrm{~cm} / \mathrm{k} . \mathrm{y}$. for Site 805 , and $2-2.5 \mathrm{~cm} / \mathrm{k} . \mathrm{y}$. for Site 806 in the Pliocene-Pleistocene.

From shipboard paleomagnetic analyses of archive sections, several intervals of anomalous magnetization were observed in the Brunhes and Matuyama chrons, possibly correlating with previously postulated short polarity intervals. However, the intensity of magnetization abruptly dropped below the noise level of the shipboard magnetometer at a common sub-bottom depth in all holes drilled at a given site. The "critical depth" varied with water depth and latitude (e.g., distance from the zone of equatorial upwelling) and was postulated to mark postdepositional dissolution of magnetite (Tarduno et al., 1991a; see also Karlin and Levi, 1983, 1985; Canfield and Berner, 1987). From sub-bottom depths less than the "critical depth," the paleomagnetic records appear unaffected. The purpose of this initial analysis of the dedicated cores is to examine further the existence of short polarity intervals in the Pliocene-Pleistocene Ontong Java section.

\section{METHODS}

Continuous natural remanent magnetization (NRM) measurements of archive half cores were performed at $1-\mathrm{cm}$ intervals using the 3-axis $2 \mathrm{G}$ Enterprises pass-through cryogenic magnetometer (identical to that on board the JOIDES Resolution) at Scripps Institution of Oceanography. The axial magnetic measurements were then converted to relative declination, inclination, and magnetization by assuming an effective volume for each axis. Magnetic susceptibility was also measured for the same interval, using a Bartington susceptibility coil $(\mathrm{ID}=100 \mathrm{~cm})$ mounted on the same track. We then measured the remanence of the archive half cores after successive demagnetization in alternating fields up to $15 \mathrm{mT}$ (in two steps: 10 and $15 \mathrm{mT}$ ).

Results obtained from continuous measurements allowed us to focus our study on short magnetic anomalies detected between the Jaramillo and Olduvai subchrons (see below). We took three "U-channel" samples from the working-half cores. These long pieces of $2.5 \times$ $2.5 \mathrm{~cm}$ U-channels (Tauxe et al., 1983) were partially demagnetized in a 5-mT alternating field (AF) and measured at 1-cm intervals using the $2 \mathrm{G}$ magnetometer. After these measurements, the sediment was carefully removed from the U-channels, cut into discrete samples ( $1 \mathrm{~cm}$ thick), and placed into nonmagnetic plastic cubes. A complete paleomagnetic study using both thermal and AF demagnetization was then conducted on these samples (see "Paleomagnetic Analyses" section, this chapter) using the CTF 3-axis cryogenic magnetometer at the Scripps paleomagnetic laboratory. We also investigated the rock magnetic characteristics of the sediment (hysteresis parameters and isothermal remanent magnetization [IRM]) using an alternating gradient force magnetometer (AGFM, Princeton Measurements Corporation Micromag 2900) at Scripps.

\section{CONTINUOUS MEASUREMENTS ON HALF CORES}

\section{Hole 803A}

The magnetic record obtained from the archive halves of cores from Hole $803 \mathrm{~A}$ after AF demagnetization at $15 \mathrm{mT}$ is shown in Figure 1. Because these cores are azimuthally unoriented, the declinations of each core have been adjusted such that the mean for normal polarity intervals is about $0^{\circ}$. The inclinations are highly variable. As the site is equatorial, inclination alone does not provide reliable magnetostratigraphic information. Thus, all polarity information is given by changes in declination. Despite some perturbations, especially at the top of the hole where the sediment is very soft and wet and at each core top, a clear magnetic polarity zonation can be recognized. With respect to the biostratigraphic constraints and by correlation with shipboard measurements on Holes 803B and 803D (Shipboard Scientific Party, 1991), the Jaramillo and Olduvai subchrons within the Matuyama Chron are confidently identified at 10.60-11.50 and 18.65-20.75 m below seafloor (mbsf). We also identify the Gauss/ Matuyama Chron boundary at about 29.10 mbsf. In contrast, the Brunhes/Matuyama boundary is more difficult to identify because it apparently occurs between cores at about 7-8 mbsf. We did not take continuous measurements on cores below Section 130-803A-4H-4 because the magnetic remanence of these sediments became abruptly very weak, below the noise level of the magnetometer. As previously mentioned, this decay in magnetization is attributed to a postdepositional dissolution of magnetite by reduction diagenesis (Tarduno et al., 1991a; Karlin and Levi, 1983, 1985; Canfield and Berner, 1987).

The polarity zonation thus obtained provides a time frame for the three well-defined magnetic zones between the Jaramillo and the Olduvai subchrons (labeled 1-3, Fig. 1). These zones, characterized by a large change in declination, are observed within the second core (respectively, Sections 130-803A-2H-4, -2H-5, and -2H-6), between 13 and 16 mbsf. In Figure 2, we show the changes in intensity, declination, and inclination for these three sections before and after $\mathrm{AF}$ demagnetization at $15 \mathrm{mT}$. This partial demagnetization removes most of the apparent noise in the directional data. The amplitude of the changes in declination also decreased for two of the three anomalies (features 2 and 3, in Fig. 2). We observe that a very small feature at about 16.6 mbsf disappears after the AF demagnetization. Comparison with the magnetic records obtained from other holes of Site 803 are favorable. In particular, the same zones seem to be observed in Hole 803B (Fig. 3). The record collected on board the JOIDES Resolution shows clearly one anomaly (labeled 1 on the Fig. 1) that could be related to the first one observed in Hole 803A. Perturbation in the magnetic record associated with a core break precludes a clear 

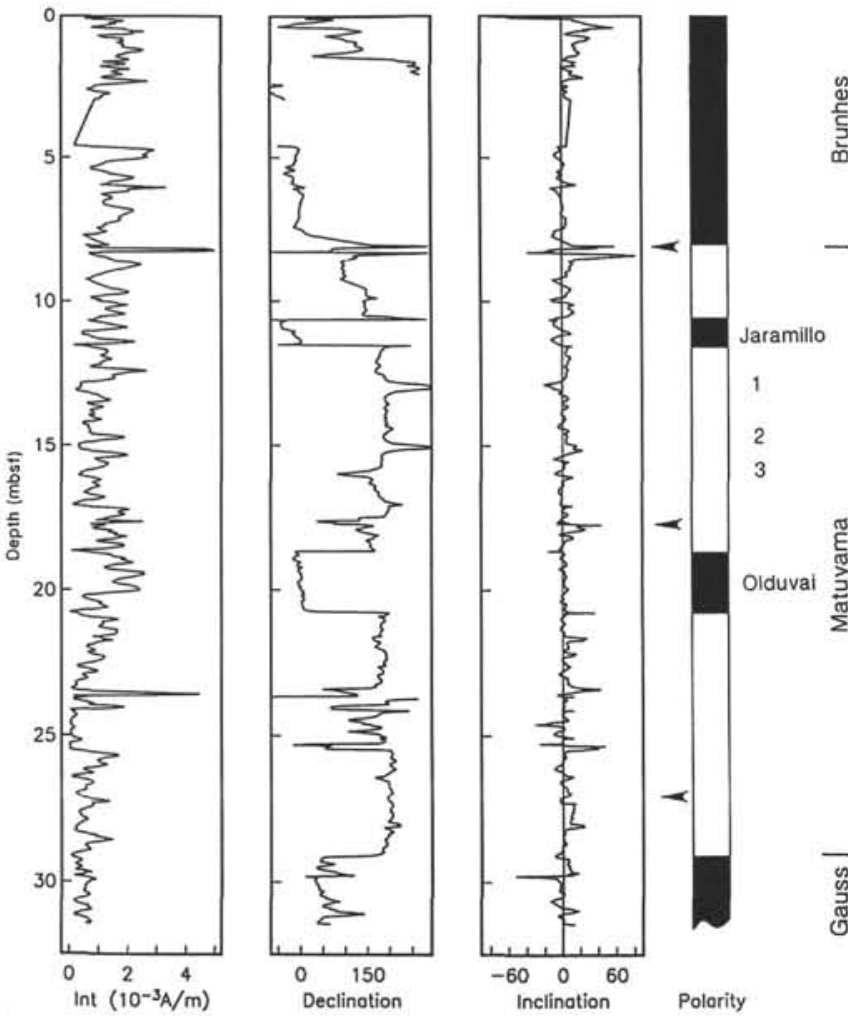

Figure 1. Magnetostratigraphy obtained from Hole 803A. Measurements were obtained using the pass-through $2 \mathrm{G}$ magnetometer at $1-\mathrm{cm}$ intervals after demagnetization in a $15-\mathrm{mT}$ alternating field. Declinations have been adjusted such that the mean for normal polarity interval is about $0^{\circ}$. Three normal magnetic anomalies, labeled $1-3$, were observed between the Jaramillo and the Olduvai subchrons (13-16 mbsf). Arrows indicate core breaks.

identification of the intermediate anomaly. However, another anomaly at about 15 mbsf could be the third one observed in Hole $803 \mathrm{~A}$.

\section{Holes 805A and 806A}

In contrast to the previous record, Holes $805 \mathrm{~A}$ and $806 \mathrm{~A}$ do not permit the recognition of a clear magnetostratigraphy. The abrupt decrease in intensity, again probably a result of the dissolution of magnetite, occurs at about 25 mbsf in Hole $805 \mathrm{~A}$ and $10.4 \mathrm{mbsf}$ in Hole 806A. Although no magnetic reversal can be identified in Hole 806A, the Jaramillo Subchron can be tentatively identified between 15.35 and 16.95 mbsf in Hole 805A (Fig. 4). As for Hole $803 \mathrm{~A}$, the Brunhes/Matuyama boundary seems to occur in a core break at about $12.5 \mathrm{mbsf}$. The magnetic record shows also one polarity zone between about 18.85 and 19.40 mbsf. If the identification of the Jaramillo Subchron is correct, this anomaly could correspond to the first zone recorded in Hole 803A.

\section{MEASUREMENTS ON U-CHANNELS AND DISCRETE SAMPLES}

To characterize better the significance of the magnetic zones discussed above, we subsampled three sections of Hole 803A with U-channels (respectively, Sections 130-803A-2H-4, 10-80 cm; $-2 \mathrm{H}-5$, $70-139 \mathrm{~cm}$; and $-2 \mathrm{H}-6,27-73 \mathrm{~cm})$. In general, the data from the $\mathrm{U}$-channels acquired at $1-\mathrm{cm}$ intervals using the pass-through $2 \mathrm{G}$ magnetometer yielded better defined magnetic results than those measured on half cores (Figs. 5A-5C). In the three records, a clear jump in declination of about $180^{\circ}$ was observed. The inclination data also show steeper values at the boundaries of the intervals. The
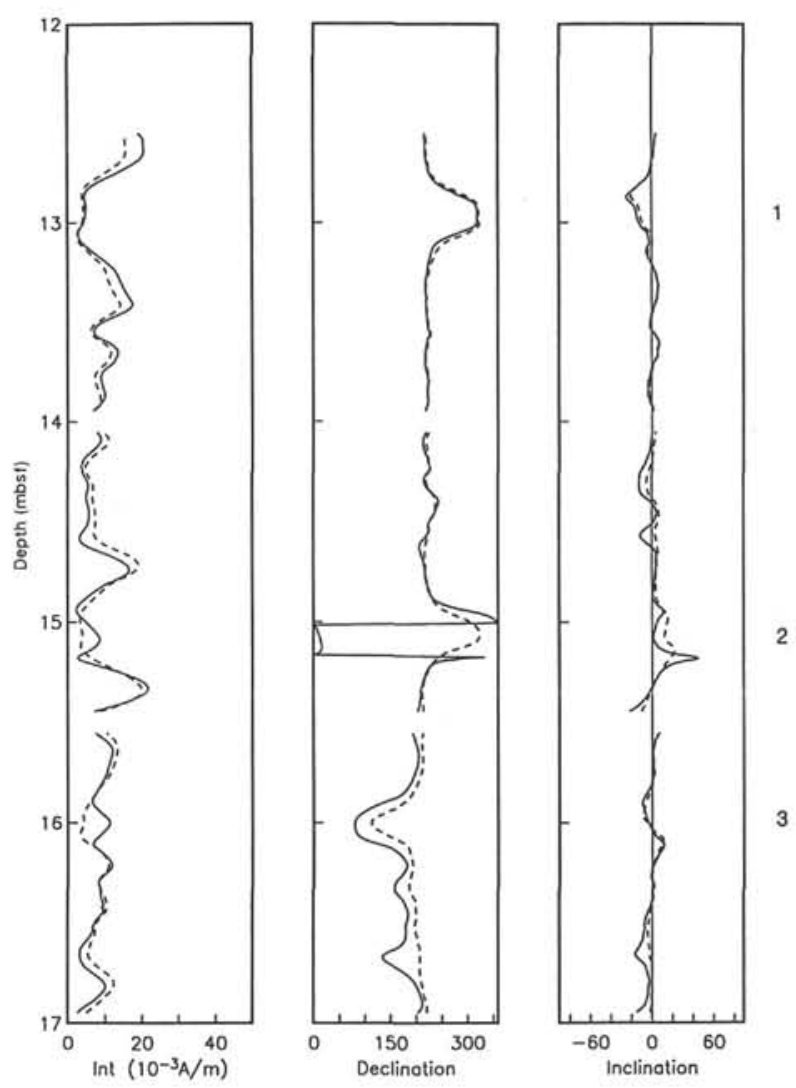

Figure 2. Comparison of magnetic records obtained at 1-cm intervals before (NRM: continuous line) and after AF demagnetization at $15 \mathrm{mT}$ (dashed lines) for the three sections of Hole $803 \mathrm{~A}(130-803 \mathrm{~A}-2 \mathrm{H}-4$ to $-2 \mathrm{H}-6)$ that display magnetic events between the Jaramillo and Olduvai subchrons. The partial demagnetization removes most of the apparent noise; however, in two cases (features 2 and 3 ), the amplitude of these anomalies decreases noticeably.

thickness of these zones is also quite similar (about $20 \mathrm{~cm}$ ). In Sections $130-803 \mathrm{~A}-2 \mathrm{H}-4$ and $-2 \mathrm{H}-5$, the anomalous declinations correspond to a reduction in magnetic intensity (Section 130-803A$2 \mathrm{H}-4$ and -2H-5; Figs. 5A-5B). However, in Section 130-803A-2H-6, the low intensity is only associated with the boundaries of the anomalous magnetic zone. At the middle of this interval, the intensity is identical to that outside of the anomalous zone. This rebound behavior is also observed in Section 130-803A-2 H-5, although the intensity remains weaker within the interval.

Because continuous magnetic measurements give only a smoothed signal, the U-channels were subsampled at a $1-\mathrm{cm}$ interval to provide a higher resolution signal (Figs. 5A-5C). We also performed measurements of the bulk magnetic susceptibility in low field using a Kappabridge (KLY-2 from Geofyzika Brno). Results of susceptibility show only very weak values. For this reason, we measured each sample three times and calculated a mean. For the three records, no direct correlation was observed between the susceptibility and the magnetic intensity of the samples. The magnetic susceptibility records show fluctuations that Tarduno et al. (1991a) suggested are related to terrestrial influx and probably also to carbonate dilution. As observed with the continuous measurements on U-channels, the directional changes are closely related to a decrease in magnetic intensity. As pointed out previously, the data obtained from Section 130-803A-2H-6 show a noticeable increase in intensity at the middle of the interval. No similar trend was observed in the two other records. The changes in direction have, in the three cases, a clear signature of "real" magnetic reversal (see also Fig. 6). The changes in declination describe a "perfect" jump of $180^{\circ}$. 

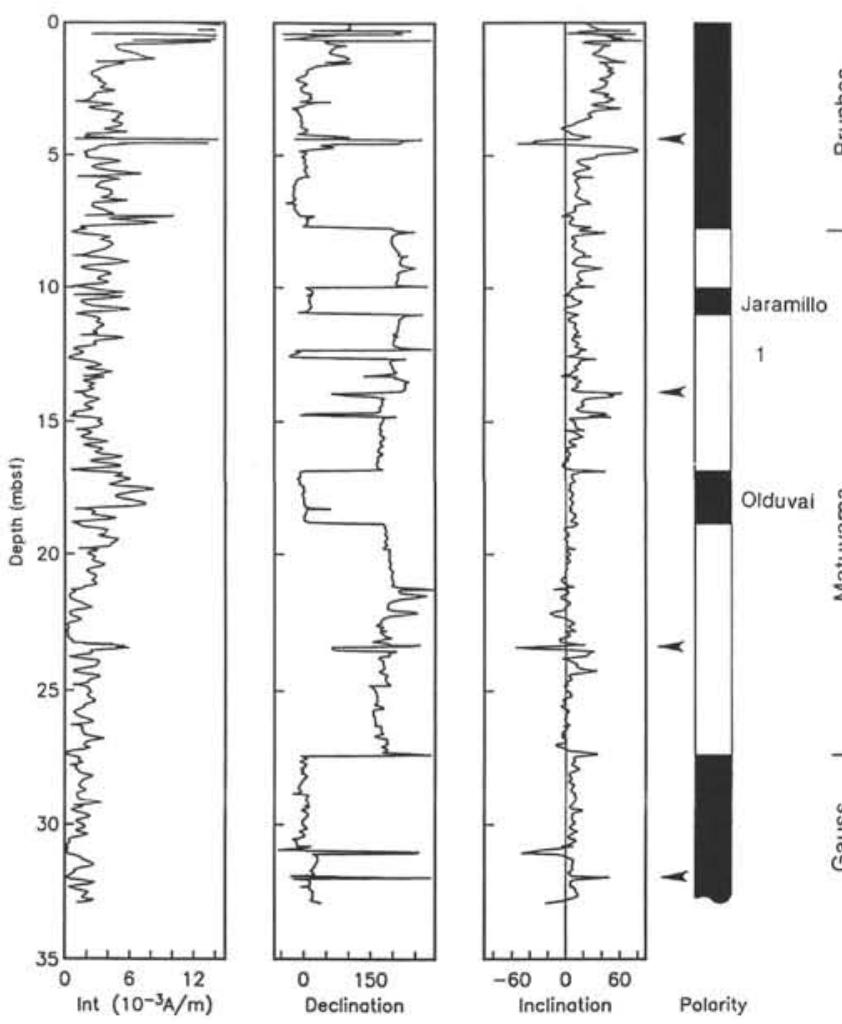

Figure 3. Magnetostratigraphy from Hole 803B obtained on board the JOIDES Resolution. Sediment was demagnetized at $15 \mathrm{mT}$. Arrows indicate core breaks. The same zones as observed in Hole 803A seem to be present in this record, although a core break precludes a clear identification of the intermediate event observed previously.

The inclinations, although possibly the result of noise, also indicate an "expected" behavior with large changes close to the limits (transitional field?) and often near zero values within the intervals (in agreement with the equatorial location of the site). This is obvious for Sections $130-803 \mathrm{~A}-2 \mathrm{H}-4$ and $-2 \mathrm{H}-5$. Although the record in inclination from Section 130-803A-2H-4 is noisier, a similar trend was also observed with the highest values close to the limits.

This study, first on half cores, then on U-channels, and finally on thin discrete samples will provide a good opportunity to test the method of deconvolution recently described by Constable and Parker (1991) using the same criterion as in the construction of cubic spline interpolators. In this method, a smoothest magnetization model is estimated considering the measured data and the observational error (magnetization of the boat carrying the section or the U-channel, noise level of the $2 \mathrm{G}$ magnetometer). We plotted together the respective records obtained by continuous measurements on U-channel and measurements of discrete samples (Figs. 5A-5C). Some differences are noticeable. For example, we observe a difference in the thickness of the upper anomalous zone (Fig. 5A). In the following section, the paleomagnetic analysis of these samples will show that this difference is related to the acquisition of a viscous remanent magnetization (VRM; see below). Such a difference was not observed in the two other zones (Figs. 5B-5C). However, for these intervals, the inclinations have an opposite behavior at their upper boundary. Deconvolution should determine if this can be explained by the effect of the response function of the $2 \mathrm{G}$ magnetometer.

\section{PALEOMAGNETIC ANALYSES}

We investigated the magnetic characteristics of Sections 130803A-2H-5 and -2H-6, assuming a similar behavior in Section 130-
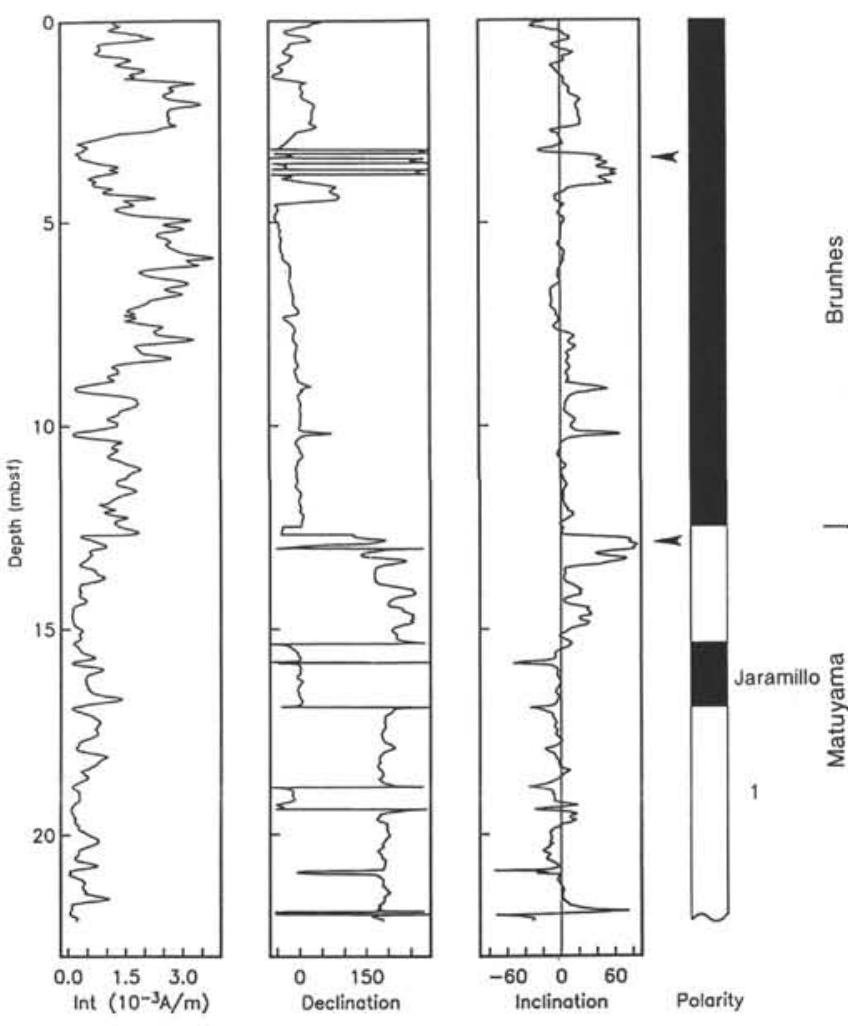

Figure 4. Magnetostratigraphy after partial demagnetization $(15 \mathrm{mT})$ of Hole $805 \mathrm{~A}$. Arrows indicate core breaks. The normal polarity interval observed between 15.35 and 16.95 mbsf is identified as the Jaramillo Subchron. The zone recognized between 18.85 and $19.40 \mathrm{mbsf}$ is tentatively correlated to the first zone observed in Hole 803A (at 13 mbsf in Figs. 1 and 2).

803A-2H-4. We measured hysteresis parameters using an AGFM for samples taken inside and outside of the anomalous zones. The data, shown in Figure 7A, show no significant change in the grain-size population within the two sections. These values are very similar to those obtained from Core ERDC113p, also on the Ontong Java Plateau (Tauxe and Wu, 1990). Thus, this result seems to indicate that changes in susceptibility are controlled by changes in magnetic grain concentration. Together with measurements of the acquisition of IRM for samples in Section 130-803A-2H-6 (Figs. 7B-7C), illustrating that saturation achieved in fields $<0.3 \mathrm{~T}$, the results are consistent either with a magnetite carrier in the pseudo-single domain (PSD) range or with a quite uniform mixture of grain sizes of magnetite. A magnetization mainly carried by magnetite is also supported by maximum blocking temperatures of about $575^{\circ} \mathrm{C}$ during stepwise thermal demagnetization (Fig. 8A). Alternating-field demagnetization, however, does not permit complete demagnetization of the samples (Fig. 8B). A component of medium-high coercivity ( $>50 \mathrm{mT}$ ) is present and cannot be properly removed. From about $35 \mathrm{mT}$, double demagnetization results differ significantly, indicating the acquisition of spurious anhysteretic remanence (ARM). For this reason, we thermally demagnetized about 25 samples within each zone, mostly centered on the normal magnetic intervals.

Examples of thermal and AF demagnetization for samples inside the three anomalous intervals are given in Figure 9. Only Sample 24-40 in the upper zone (Section 130-803A-2H-4, at $40 \mathrm{~cm}$, Fig. 9A) shows a single component of normal polarity. When thermally demagnetized, samples from the other zones clearly show two components of opposite magnetic polarity (Figs. 9B-9C, samples from Section 130-803A-2H-5; Figs. 9E-9F, samples from Section 130-803A-2H-6). A component of normal polarity is initially removed in the temperature range from $0^{\circ}$ to $250^{\circ} \mathrm{C}$, followed by a component of reversed polarity in the higher 
blocking temperature range. As previously pointed out, only the normal polarity component can be removed by AF demagnetization (Figs. 9D and 9G), in a range from 0 to $40 \mathrm{mT}$. A component of medium-high coercivity, always of reversed polarity, cannot be demagnetized because of its coercivity as well as the ARM acquired during demagnetization. In view of the consistency of the hysteresis parameters (Fig. 7), this paleomagnetic behavior might be explained by a uniform mixture of coarse and fine grains of magnetite. The coarser fraction carrying a normal magnetic direction is easily demagnetized at $250^{\circ} \mathrm{C}$ or about $30-40 \mathrm{mT}$. The fine fraction of magnetite with a reversed polarity magnetic direction can be only demagnetized by thermal treatment in the medium-high temperature range, whereas this component remains after $\mathrm{AF}$ demagnetization to $50 \mathrm{mT}$.

\section{DISCUSSION}

Demagnetization of samples from the upper anomalous zone (12.85-13.05 mbsf) reveals a well-defined component of normal polarity in agreement with the Cobb Mountain Subchron (Fig. 9A). Considering a constant sedimentation rate in Hole 803A between the lower boundary of the Jaramillo Subchron and the younger boundary of the Olduvai Subchron $(1.08 \mathrm{~cm} / \mathrm{k} . \mathrm{y}$.), we derive an age of about 1.1 Ma for this interval, in agreement with previous age estimates for the Cobb Mountain Subchron (Mankinen et al., 1978; Clement and Kent, 1987; Chauvin et al., 1990). The duration of this interval can also be estimated from our data to be about $22,000 \mathrm{yr}$, comparable to the 25,000 yr suggested by Clement and Kent (1987). Previously observed in northwestern America (Mankinen et al., 1978; Mankinen and Grommé, 1979), in the North Atlantic (Clement and Kent, 1987), in Polynesia (Chauvin et al., 1990), in the Celebes Sea (Hsu et al., 1990), and now in the western equatorial Pacific, this subchron clearly has a worldwide occurrence and must be considered as a true geomagnetic polarity interval. Similar estimates (although the paleomagnetic analysis is not yet completed) can be obtained from Section $130-805 \mathrm{~A}-3 \mathrm{H}-5$ (Interval 1 in Fig. 4). The identification of the Jaramillo Subchron between 15.5 and 17 mbsf allows us to evaluate a "mean" sedimentation rate of $1.7 \mathrm{~cm} / \mathrm{k} . \mathrm{y}$., yielding a mid-age of about $1.1 \mathrm{Ma}$ for the interval between 18.8 and 19.4 mbsf. Thus, this interval can also be confidently identified as the Cobb Mountain Subchron. From the continuous record obtained with the $2 \mathrm{G}$ magnetometer after a $15-\mathrm{mT}$ demagnetization, this interval has a thickness in Hole $805 \mathrm{~A}$ of about $50 \mathrm{~cm}$, which corresponds to a duration of about $29,000 \mathrm{yr}$.

The paleomagnetic analysis of samples from the intermediate and lower anomalous zones shows a more complex signature with two components of opposite polarity (Fig. 9). Rock magnetic experiments indicate little change in the distribution of magnetic mineralogy or grain size (Fig. 7), so these zones of normal polarity are not associated with specific rock magnetic characteristics. The underlying reversed polarity component could be interpreted as a postdepositional remanent magnetization (p-DRM). Indeed, it is now well accepted that sediments can acquire a magnetization after deposition (e.g., Irving and Major, 1964; Kent, 1973; Lovlie, 1974, 1976; Verosub, 1977; Tucker, 1979, 1980; van Hoof and Langereis, 1991). Instead of a model of instantaneous alignment and lock-in of magnetic grains, the grains are gradually locked over a zone of "consolidation" (Denham and Chave, 1982). This behavior has been observed in redeposition experiments of synthetic sediment (e.g., Lovlie, 1974; Tucker, 1979) and also from natural marine sections (van Hoof and Langereis, 1991). The postdepositional realignment of a particular grain depends in some way on its size (Tucker, 1979): larger magnetic grains are locked earlier (higher) in the sediment column and smaller grains remain mobile a longer time (deeper). From this characteristic, we should observe a more or less gradual change in the temperature range of the normal component within the anomalous zones related to the change in the magnetic fraction involved in the p-DRM process. Within these anomalous zones, the thermal demagnetization of the normal component is always achieved at $250^{\circ} \mathrm{C}$, although the relative proportion of this component, relative to the final reversed component, significantly and smoothly changes throughout the anomalous zones. Because of the constant unblocking temperature of the normal component, a selective overprint (viscous remanent magnetization [VRM]) in a recent normal (Brunhes) field appears more likely.

To explain such a selective overprint in very homogeneous sediments better (in terms of magnetic properties), we plotted the respective magnetization of the normal polarity (low temperature, $0^{\circ}-250^{\circ} \mathrm{C}$ ) and reversed polarity (high temperature, $250^{\circ}-575^{\circ} \mathrm{C}$ ) components, deduced from the vector difference after each step of demagnetization. The two curves are then compared with the magnetic susceptibility (Figs. 10A-10B). Mainly from the intermediate zone (Fig. 10A), it is clear that a close correlation exists between the magnetization of the low-temperature component and the susceptibility. As previously pointed out, measurements of hysteresis parameters of Sections 130$803 \mathrm{~A}-2 \mathrm{H}-5$ and $-2 \mathrm{H}-6$ indicate that the changes in magnetic susceptibility are probably a result of changes in the magnetic concentration rather than in grain size. Therefore, we can normalize the magnetization of the low-temperature component by the magnetic concentration (susceptibility). As expected from the correlation, we obtain very uniform values (top panel, Figs. 10A-10B), which clearly show that the relative contribution of the VRM remains constant throughout the section, with no special behavior within the normal magnetic zones. These estimates seem to indicate that the two apparent normal magnetic zones are related to geomagnetic field behavior, although no true normal polarity intervals were recognized.

A tentative explanation of this behavior is suggested by the variation in the high-temperature component. A similar approach can be used assuming that this component, normalized by the susceptibility, yields some information about the relative intensity of the geomagnetic field at the time of deposition. Three rock magnetic criteria for this purpose have been suggested by King et al. (1983): (1) the remanence must be carried by small $1-15 \mathrm{~mm}$ magnetite grains, (2) the magnetic concentration must have a relative homogeneity, and (3) the remanence must be normalized by a parameter that takes into account the variability of the magnetic grains. We have not conducted such an extensive analysis in our study (e.g., Tauxe and $\mathrm{Wu}, 1990$ ). We simply assume that the magnetic susceptibility is a relevant parameter to normalize the remanence (third criterion). Following this assumption, we note that the two anomalous zones are related to low "paleointensity," which might correspond to a low dipole field.

To test the first-order accuracy of this observation, we performed a similar analysis for the Cobb Mountain Subchron (Fig. 11). Again, the low-temperature component $\left(0^{\circ}-120^{\circ} \mathrm{C}\right)$, when normalized by the susceptibility, yielded very uniform values that displayed no particular enhancement of VRM acquisition. The normalized hightemperature component (about $200^{\circ}-575^{\circ} \mathrm{C}$ ) provides a more characteristic pattern, with (1) rapid changes close to the normal to reversed polarity transition and a very weak paleointensity at the transition, (2) a gradual increase and then decrease within the normal interval (between 32 and $50 \mathrm{~cm}$ ), and (3) a long period of weak paleointensity at the reversed to normal polarity transition (between 50 and $60 \mathrm{~cm}$ ). The low paleointensity between 50 and $60 \mathrm{~cm}$ can explain the difference we noticed in Figure $5 \mathrm{~A}$ between the first measurements obtained from the $2 \mathrm{G}$ magnetometer and those obtained from the discrete samples; this behavior may also be close to that observed in the two other anomalous zones. Some confidence in the reliability of our paleointensity record is obtained when we compare this record with the magnetic intensity fluctuations during the Cobb Mountain Subchron inferred from sediments in the North Atlantic (Clement and Kent, 1987). The two curves are very similar, although the sedimentation rates between these two sections are very different (about $1.1 \mathrm{~cm} / \mathrm{k} . \mathrm{y}$. in Hole $803 \mathrm{~A}$; about $8 \mathrm{~cm} / \mathrm{k} . \mathrm{y}$. in Hole 609B; Clement and Kent, 1987). This good agreement seems to support the 
A
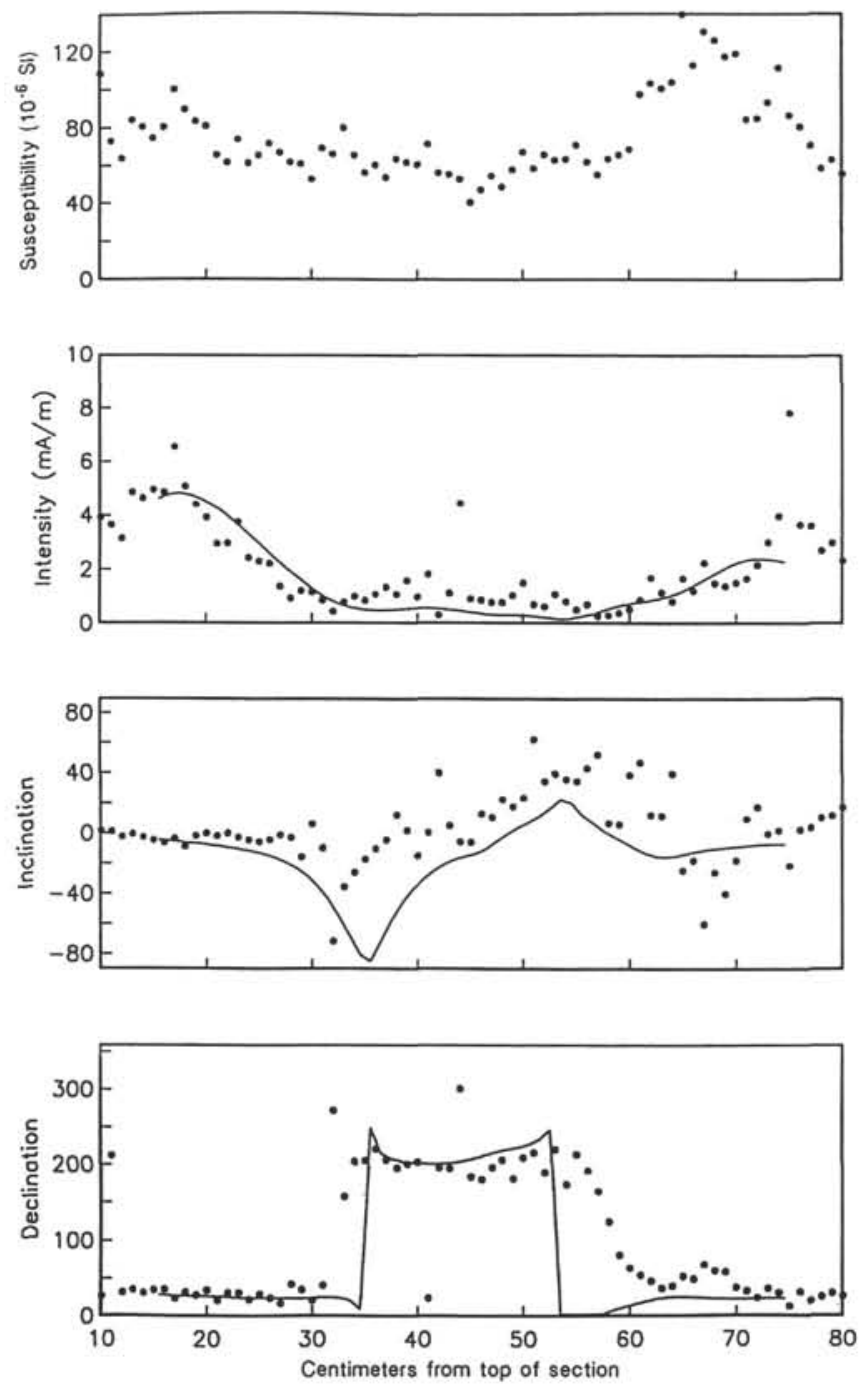

B
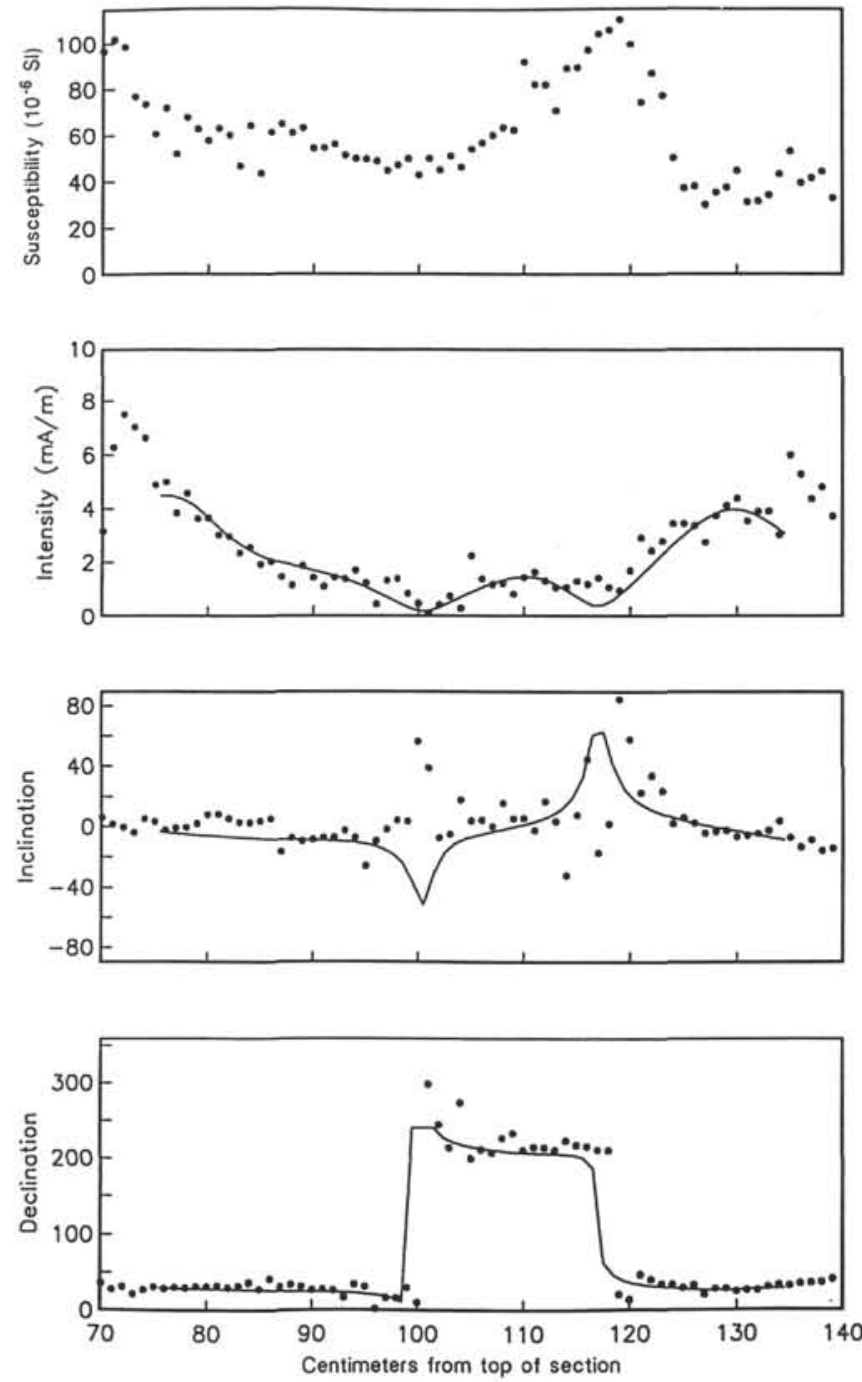

Figure 5. Magnetization at 1-cm intervals of three U-channels (line) collected from working-half sections (Sections 130-803A-2H-4 [A], $-2 \mathrm{H}-5$ [B], and -2H-6 $[\mathrm{C}]$ ) and discrete sample data (solid circles). The depths are relative to the top of the respective sections, and declinations are relative to the fiducial mark on the unoriented cores. A weak demagnetization at $5 \mathrm{mT}$ has been performed. The three magnetic anomalous zones previously observed between the Jaramillo and Olduvai subchrons are clearly defined by a jump in declination of about $180^{\circ}$. In Figures $5 \mathrm{~A}$ and $5 \mathrm{~B}$, the changes in direction are associated with a low magnetic intensity. For the third (lower) U-channel, a decrease in intensity is only noted at the limits of the interval. Measurements of the magnetic susceptibility show no correlation with the intensity $(\mathrm{A} / \mathrm{m})$.

hypothesis that, in our study, the normalized high-temperature component yields a reasonable estimate of the relative paleointensity of the geomagnetic field. By analogy, the intermediate and lower anomalous zones are probably also related to a low geomagnetic field. As a matter of interest, the mean sedimentation rate in Hole $803 \mathrm{~A}$ provides an age of about $1.3 \mathrm{Ma}$ for the intermediate zone and about 1.4 Ma for the lower one. However, the lack of similar behavior in other studies precludes a definitive answer. Only detailed paleointensity analyses from sediments in Pacific or other oceans could constrain the geomagnetic intensity fluctuations throughout the Matuyama Chron.

\section{CONCLUSION}

A detailed magnetostratigraphic study from Hole 803A documents three normal polarity magnetic intervals in the NRM of sediments between the Jaramillo and Olduvai subchrons. The upper interval is confidently correlated to the Cobb Mountain Subchron at about 1.1 Ma, whereas the two other anomalous zones appear to be the result of the dominant contribution of VRM acquisition. The normalization of VRM by susceptibility and the lack of any change in magnetic properties through the anomalous zones seem to show that these two intervals result from low NRM related perhaps to low geomagnetic field intensity.

\section{ACKNOWLEDGMENTS}

We thank Gerald Bode and Steve Prinz from the ODP West Coast Repository and Warren Smith from SIO for their help during the sub-sampling. We also thank J. LaBrecque and one anonymous reviewer for their critical readings of the manuscript. This work was partly supported by USSAC Grant P.O. \#20462 to L.T. and J.T., and a NATO postdoctoral fellowship to Y.G. IPGP contribution \#1216. Contribution INSU-CNRS DBT Thème Message Sédimentaire \#468. 

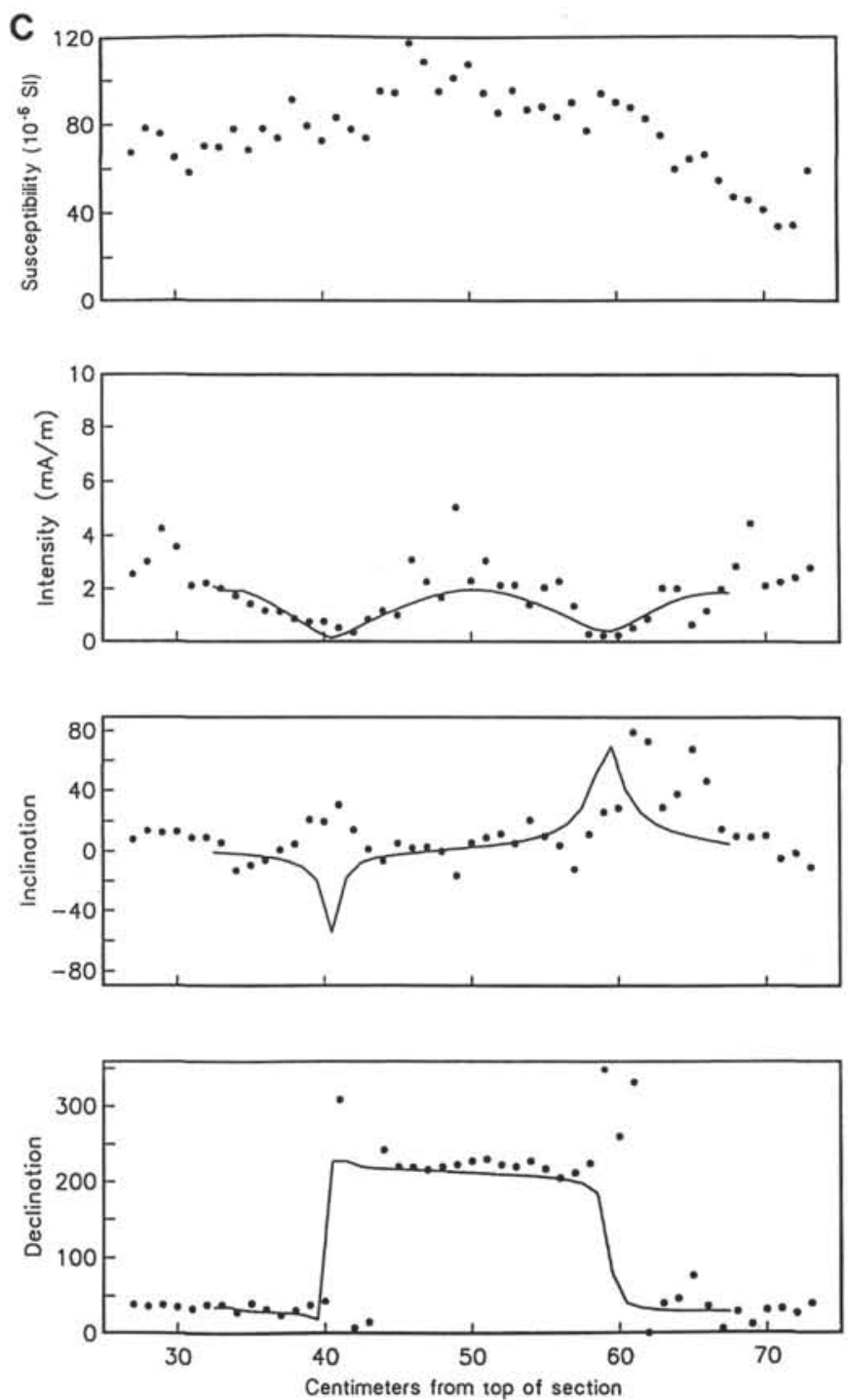

Figure 5 (continued).

\section{REFERENCES}

Blakely, R.J., 1974. Geomagnetic reversals and crustal spreading rates during the Miocene. J. Geophys. Res., 79:2979-2985.

Blakely, R.J., and Cox, A., 1972. Evidence for short geomagnetic polarity intervals in the early Cenozoic. J. Geophys. Res., 77:7065-7072.

Cande, S.C., and LaBrecque, J.L., 1974. Behavior of the Earth's paleomagnetic field from small scale marine magnetic anomalies. Nature, 247:26-28

Canfield, D.E., and Berner, R.A., 1987. Dissolution and pyritization of magnetite in anoxic marine sediments. Geochim. Cosmochim. Acta, 51:645-659.

Champion, D., Lanphere, M., and Kuntz, M., 1988. Evidence for a new geomagnetic reversal from lava flows in Idaho: discussion of short polarity reversals in the Brunhes and late Matuyama chrons. J. Geophys. Res., 93:11667-11680.

Chauvin, A., Roperch, P., and Duncan, R.A., 1990. Records of geomagnetic reversals from volcanic islands of French Polynesia. 2. Paleomagnetic study of a flow sequence (1.2-0.6 Ma) from the Island of Tahiti and discussion of reversal models. J. Geophys. Res., 95:2737-2752.

Clement, B., and Kent, D., 1987. Short polarity intervals within the Matuyama: transitional field records from hydraulic piston cored sediments from the Northern Atlantic. Earth Planet. Sci. Lett., 81:253-264.

Constable, C., and Parker, R., 1991. Deconvolution of long-core palaeomagnetic measurements-spline therapy for the linear problem. Geophys. J. Int., 104:453-468.
Courtillot, V., Besse, J., Vandamme, D., Montigny, R., Jaeger, J.J., and Capetta, H., 1986. Deccan flood basalts at the Cretaceous/Tertiary boundary? Earth Planet. Sci. Lett., 80:361-374.

Cox, A., 1969. Geomagnetic reversals. Science, 163:237-245.

Creer, K.M., Readman, P.W., and Jacobs, A.M., 1980. Paleomagnetic and paleontological dating of a section at Gioia Tauro, Italy: identification of the Blake event. Earth Planet. Sci. Lett., 50:289-300.

Denham, C.R., 1976. Blake polarity episode in two cores from the greater Antilles outer ridge. Earth Planet. Sci. Lett, 29:422-434.

Denham, C.R., and Chave, A.D., 1982. Detrital remanent magnetization: viscosity theory of the lock-in zone. J. Geophys. Res., 87:7126-7130.

Duffield, W.A., Bacon, C.R., and Dalrymple, G.B., 1980. Late Cenozoic volcanism, geochronology, and structure of the Coso Range, Inyo County, California. J. Geophys. Res., 85:2381-2404.

Emilia, D.A., and Heinrichs, D.F., 1969. Ocean floor spreading: Olduvai and Gilsa events in the Matuyama epoch. Science, 166:1267-1269.

Grommé, C.S., and Hay, R.L., 1971. Geomagnetic polarity epochs: age and duration of the Olduvai normal polarity event. Earth Planet. Sci. Lett., 10:179-185.

Harland, W.B., Armstrong, R.L., Cox, A.V., Craig, L.E., Smith, A.G., and Smith, D.G., 1989. A Geologic Time Scale: Cambridge (Cambridge Univ. Press).

Heirtzler, J.R., Dickson, G.O., Herron, E.M., Pitman, W.C., III, and LePichon, X., 1968. Marine magnetic anomalies, geomagnetic field reversals and motions of the ocean floor and continents. J. Geophys. Res., 73:2119-2136.

Hsu, V., Merrill, D.L., and Shibuya, H., 1990. Paleomagnetic transition records of the Cobb Mountain event from sediments of the Celebes and Sulu seas. Geophys. Res. Lett., 17:2069-2072.

Irving, E., and Major, A., 1964. Post-depositional remanent magnetization in a synthetic sediment. Sedimentology, 3:135-143.

Karlin, R., and Levi, S., 1983. Diagenesis of magnetic minerals in recent hemipelagic sediments. Nature, 303:327-330.

1985. Geochemical and sedimentological control of the magnetic properties of hemipelagic sediments. J. Geophys. Res., 90:10373-10392.

Kent, D.V., 1973. Post-depositional remanent magnetization in deep-sea sediment. Nature, 246:32-34.

Kent, D.V., and Spariosu, D.J., 1982. Magnetostratigraphy of Caribbean site 502 hydraulic piston cores. In Prell, W.L., Gardner, J.V., et al., Init. Repts. DSDP, 68: Washington (U.S. Govt. Printing Office), 419-433.

King, J.W., Banerjee, S.K., and Marvin, J., 1983. A new rock-magnetic approach to selecting sediments for geomagnetic paleointensity studies: application to paleointensity for the last 4000 years. J. Geophys. Res., 88:5911-5921.

LaBrecque, J.L., Kent, D.V., and Cande, S.C., 1977. Revised magnetic polarity time scale for Late Cretaceous and Cenozoic time. Geology, 5:330-335.

Lovlie, R., 1974. Post-depositional remanent magnetization in a re-deposited deep-sea sediment. Earth Planet. Sci. Lett., 21:315-320.

1976. The intensity pattern of post-depositional remanence acquired in some marine sediments deposited during a reversal of the external magnetic field. Earth Planet. Sci. Lett., 30:209-214.

Lowrie, W., 1989. Magnetic polarity time scales and reversal frequency. In Lowes, F.J., Collinson, D., Parry, J., Runcorn, S., Tozer, D., and Soward, A. (Eds.), Geomagnetism and Palaeomagnetism. NATO ASI, 155-183.

Lowrie, W., and Kent, D., 1983. Geomagnetic reversal frequency since the Late Cretaceous. Earth Planet. Sci. Lett., 62:305-313.

McDougall, I., and Watkins, N.D., 1973. Age and duration of the Réunion geomagnetic polarity event. Earth Planet. Sci. Lett., 19:443-452.

McFadden, P.L., and Merrill, R.T., 1984. Lower mantle convection and geomagnetism. J. Geophys. Res., 89:3354-3362.

Mankinen, E.A., and Dalrymple, G.B., 1979. Revised geomagnetic polarity time scale for the interval 0-5 m.y. B.P. J. Geophys. Res., 84:615-626.

Mankinen, E.A., Donnelly, J., and Grommé, C.S., 1978. Geomagnetic polarity event recorded at 1.1 m.y. B.P. on Cobb Mountain, clear Lake volcanic field, California. Geology, 6:653-656.

Mankinen, E.A., and Grommé, C.S., 1982. Paleomagnetic data from the Coso Range, California and current status of the Cobb Mountain normal geomagnetic polarity event. Geophys. Res. Lett., 9:1279-1282.

Shipboard Scientific Party, 1991. Site 803. In Kroenke, L.W., Berger, W.H., Janecek, T.R., et al., Proc. ODP, Init. Repts., 130: College Station, TX (Ocean Drilling Program), 101-176.

Smith, J.D., and Foster, J.H., 1969. Geomagnetic reversal in Brunhes normal polarity epoch. Science, 163:565-567.

Tarduno, J.A., Mayer, L.A., Musgrave, R., and Shipboard Scientific Party, 1991a. High-resolution, whole-core magnetic susceptibility data from 
Leg 130, Ontong Java Plateau. In Kroenke, L.W., Berger, W.H., Janecek, T.R., et al., Proc. ODP, Init. Repts., 130: College Station, TX (Ocean Drilling Program), 541-548.

Tarduno, J.A., Sliter, W.V., Kroenke, L., Leckie, M., Mayer, H., Mahoney, J.J., Musgrave, R., Storey, M., and Winterer, E.L., 1991b. Rapid formation of Ontong Java Plateau by Aptian Mantle plume volcanism. Science, 18:399-403.

Tauxe, L., LaBrecque, J.L., Dodson, R., and Fuller, M., 1983. "U" channels new technique for paleomagnetic analysis of hydraulic piston core. Eos, 64:219. (Abstract)

Tauxe, L., Valet, J.-P., and Bloemendal, J., 1989. Magnetostratigraphy of Leg 108 advanced hydraulic piston cores. In Ruddiman, W., Sarnthein, M., et al., Proc. ODP, Sci. Results, 108: College Station, TX (Ocean Drilling Program), 429-439.

Tauxe, L., and Wu, G., 1990. Normalized remanence in sediments of the western equatorial Pacific: relative paleointensity of the geomagnetic field? J. Geophys. Res., 95:12337-12350.

Tric, E., Laj, C., Valet, J.P., Tucholka, P., Paterne, M., and Guichard, F., 1991. The Blake geomagnetic event: transition geometry, dynamical characteristics and geomagnetic significance. Earth Planet. Sci. Lett., 102:1-13.

Tucholka, P., Fontugne, M., Guichard, F., and Paterne, M., 1987. The Blake magnetic polarity episode in cores from the Mediterranean Sea. Earth Planet. Sci. Lett., 86:320-326.
Tucker, P., 1979. Selective post-depositional realignment in a synthetic sediment. Phys. Earth Planet. Inter, 20:11-14.

, 1980. A grain mobility model of post-depositional realignment. Geophys. J.R. Astron. Soc., 63:149-163.

Vandamme, D., Courtillot, V., Besse, J., and Montigny, R., 1991. Paleomagnetism and age determinations of the Deccan traps (India): results of a Nagpur-Bombay traverse and review of earlier work. Rev. Geophys., 29:159-190.

van Hoof, A., and Langereis, C., 1991. Reversal records in marine marls and delayed acquisition of remanent magnetization. Nature, 351:223-225.

Verosub, K.L., 1977. Depositional and post-depositional processes in the magnetization of sediments. Rev. Geophys. Space Phys., 15:129-143.

Watkins, N.D., 1968. Short period geomagnetic polarity events in deep-sea sedimentary cores. Earth Planet. Sci. Lett., 4:341-349.

Watkins, N.D., Kristjansson, L., and, McDougall, L., 1975. A detailed paleomagnetic survey of the type location for the geomagnetic polarity event. Earth Planet. Sci. Lett., 27:436-444.

Date of initial receipt: 25 November 1991

Date of acceptance: 22 June 1992

Ms 130B-033

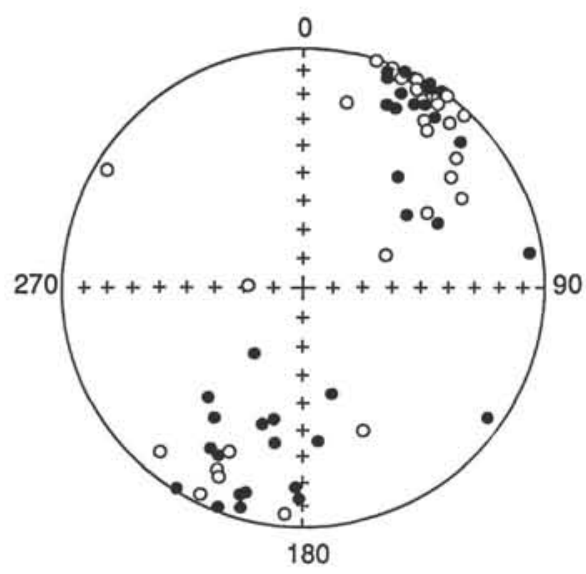

$130-803 \mathrm{~A}-2 \mathrm{H}-4$

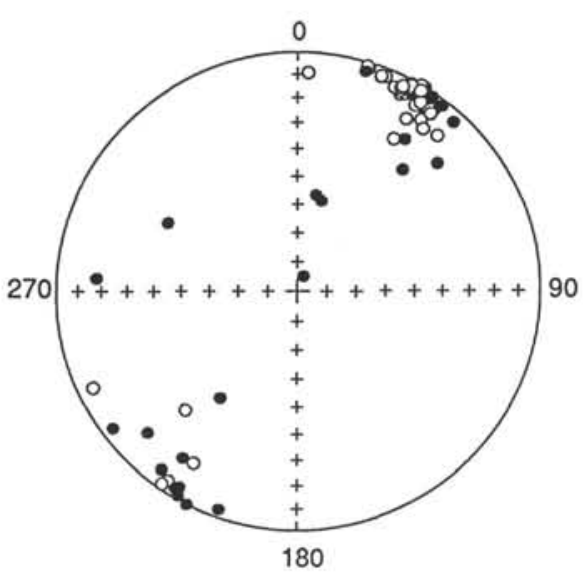

$130-803 \mathrm{~A}-2 \mathrm{H}-5$

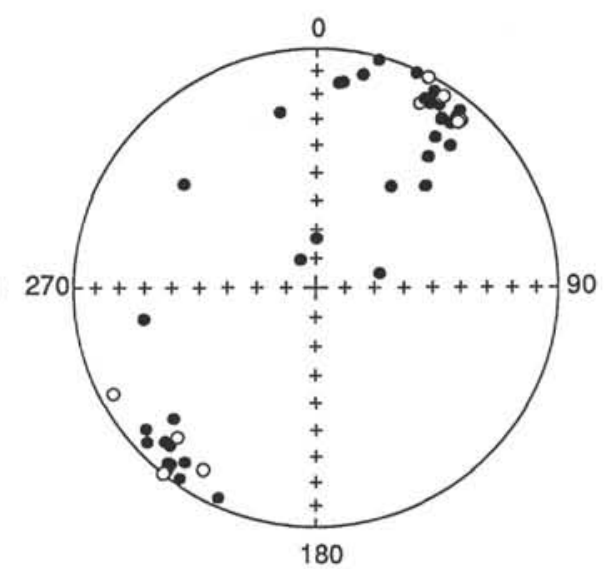

$130-803 \mathrm{~A}-2 \mathrm{H}-6$

Figure 6. Directional data obtained from the discrete samples. Solid and open circles represent directions in the lower and upper hemispheres, respectively. Although the sediment has been only demagnetized in $5 \mathrm{mT}$, apparent antipodal directions can be observed for the three events. Directions are relative to the fiducial mark on the unoriented cores. 


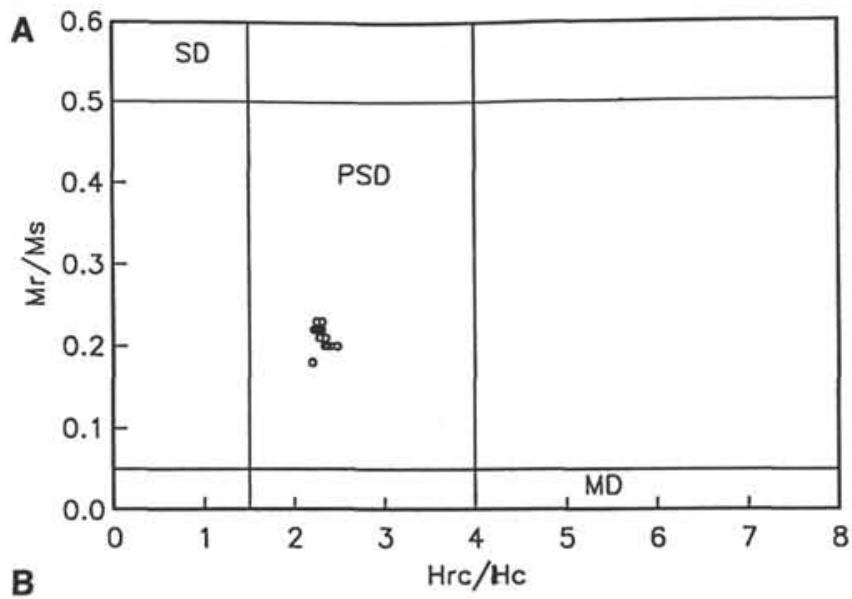

B
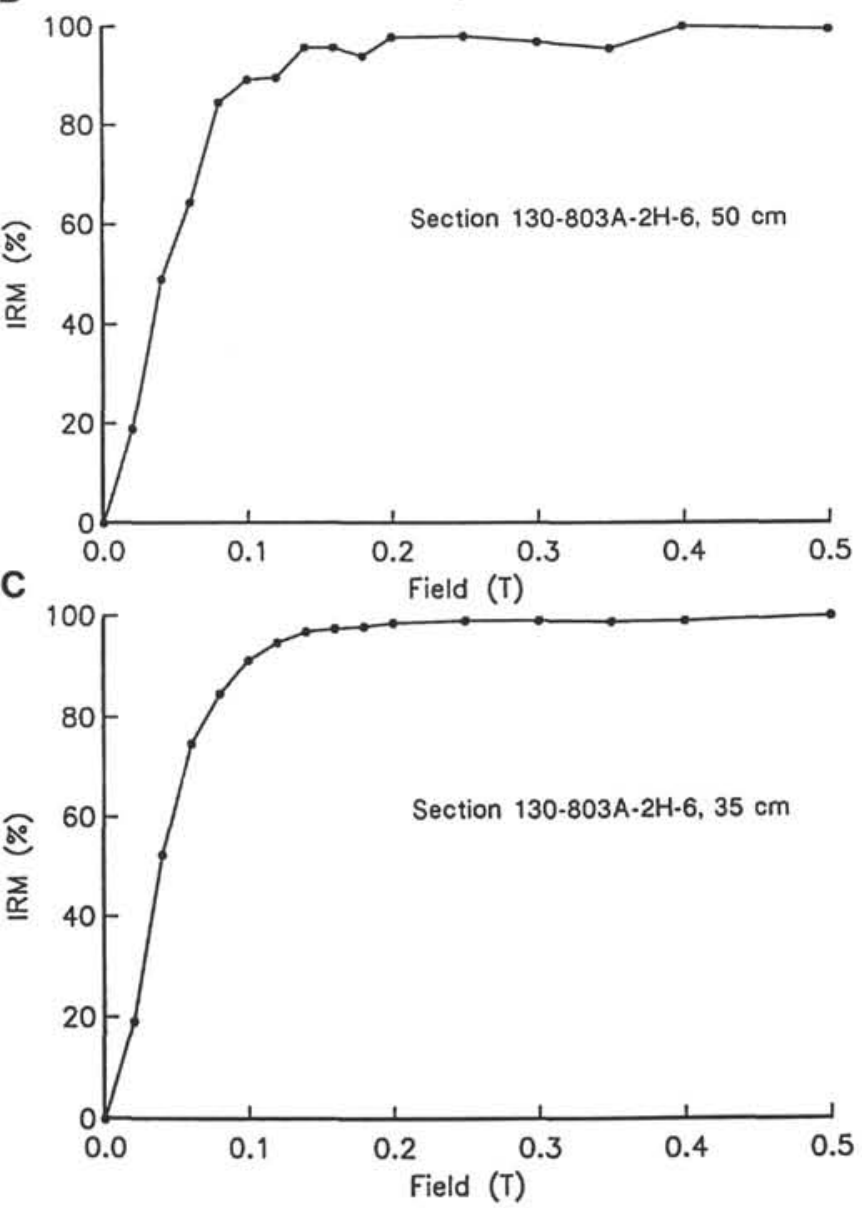

Figure 7. Rock magnetic characteristics of samples from Sections 130-803A-2H-5 and -2H-6. A. Hysteresis parameters for samples taken inside (solid circles) and outside (open circles) of the two anomalous zones. B. IRM acquisition curve for one sample above the lower normal polarity zone. C. Representative IRM acquisition for a sample in the normal polarity zone. SD, PSD, and MD = singledomain, pseudo-single-domain, and multi-domain size range, respectively. 
A Section 130-803A-2H-6, $32 \mathrm{~cm}$

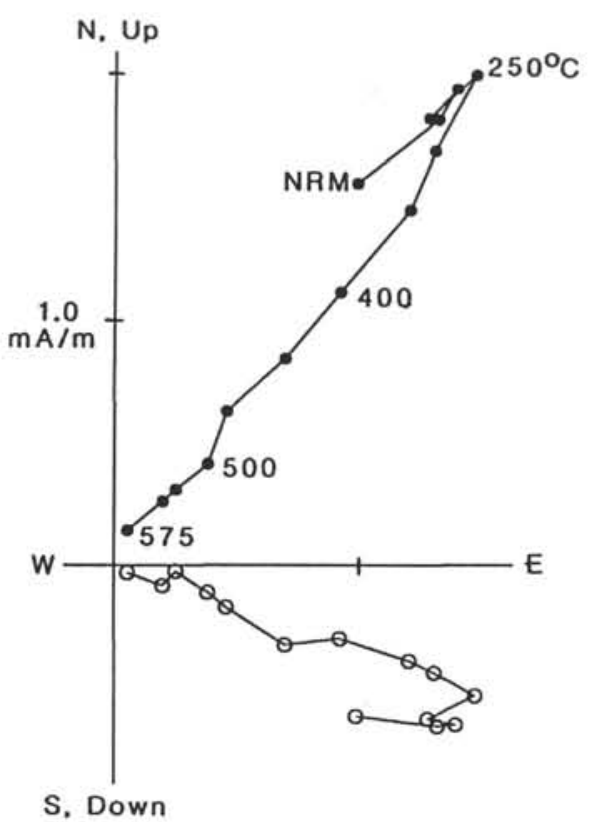

B Section 130-803A-2H-6, $66 \mathrm{~cm}$

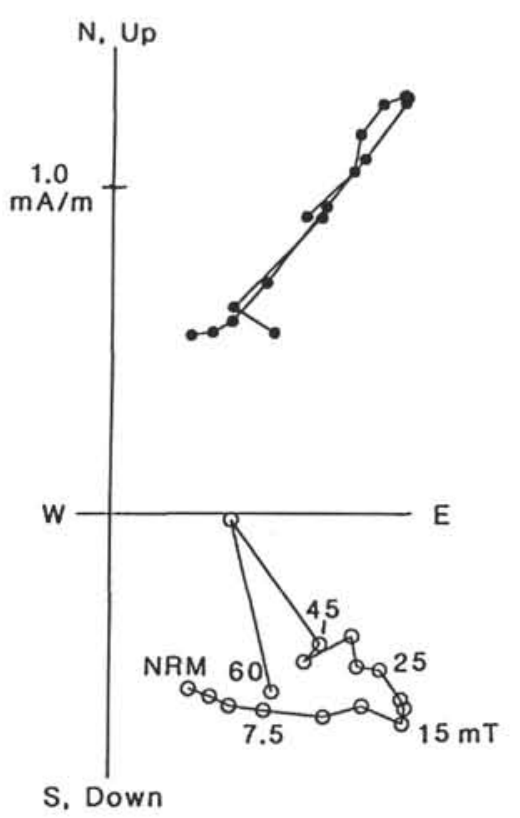

Figure 8. Comparison of vector endpoint diagrams for thermal demagnetization (A) and AF demagnetization (B) of two samples from Section 130-803A-2H-6 (reversed polarity). Solid and open symbols are projections of the remanence vector on the horizontal and vertical planes, respectively. 
A

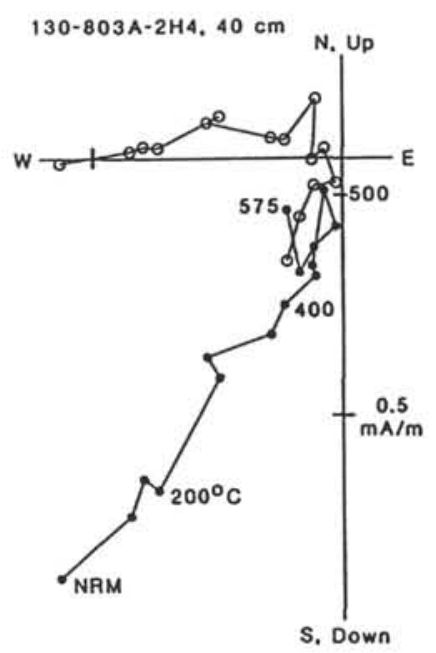

B

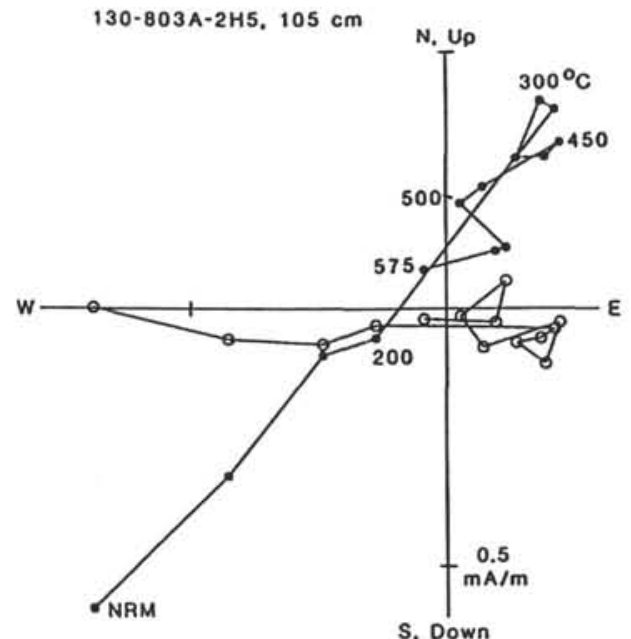

C

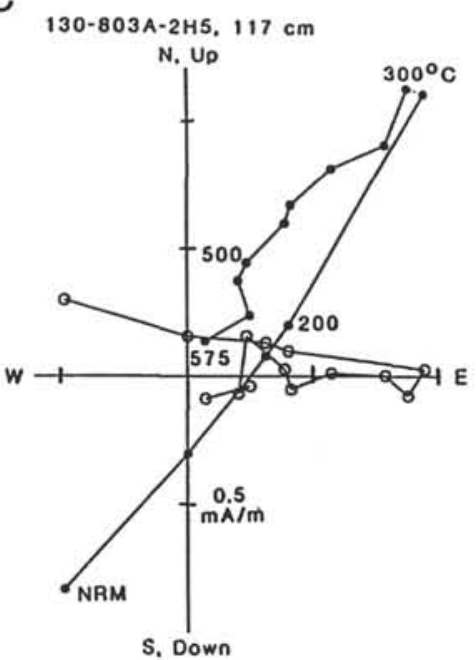

D

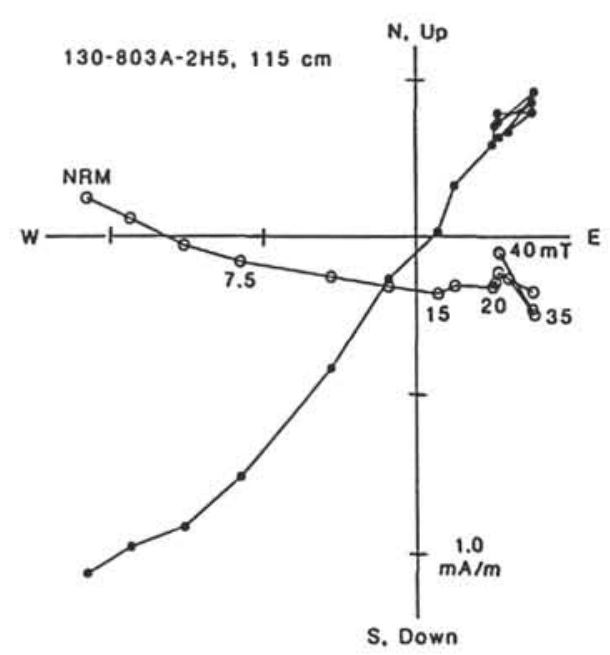

$\mathrm{F}$

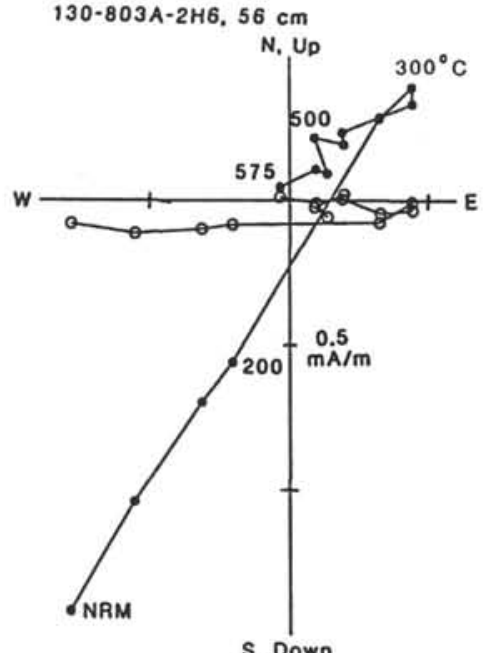

E

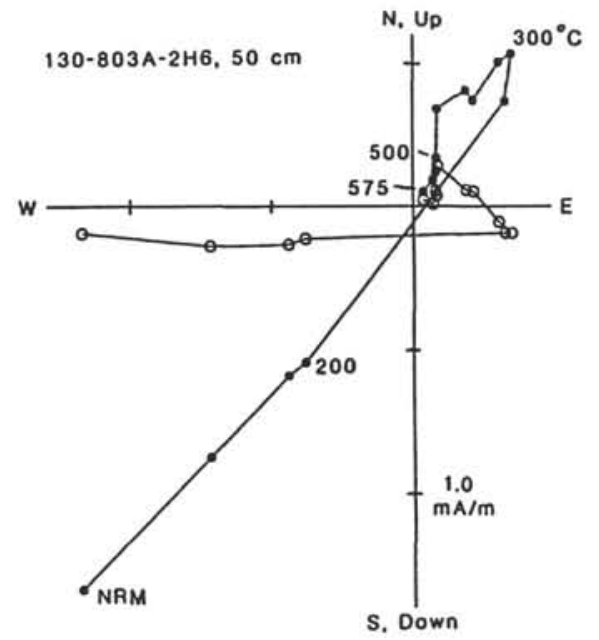

G

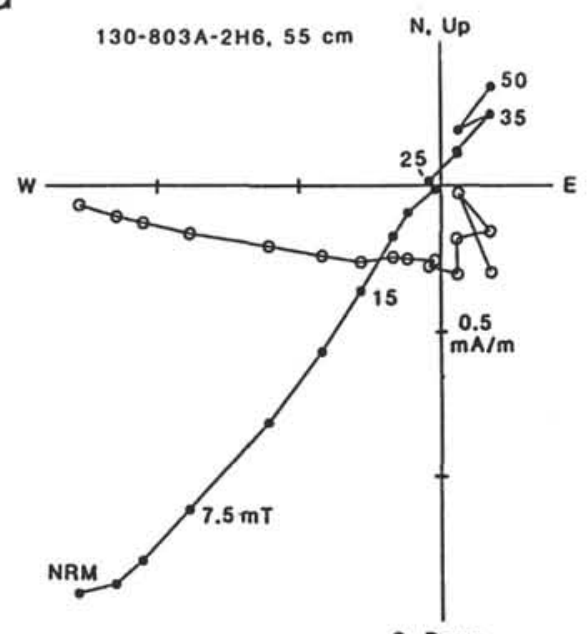

S. Down

Figure 9. Vector endpoint diagrams of samples from the three normal polarity zones. A. Thermal demagnetization of Section 130-803A-2H-4, $40 \mathrm{~cm}$, from the upper zone. B-D. Samples from the intermediate zone (Figs. 9B-9C: examples of thermal demagnetization; Fig. 9D: AF demagnetization). E-G. Samples from the lower zone (Figs. 9E-9F: thermal demagnetization; Fig. 9G: AF demagnetization). 
A

Intermediate onomalous zone
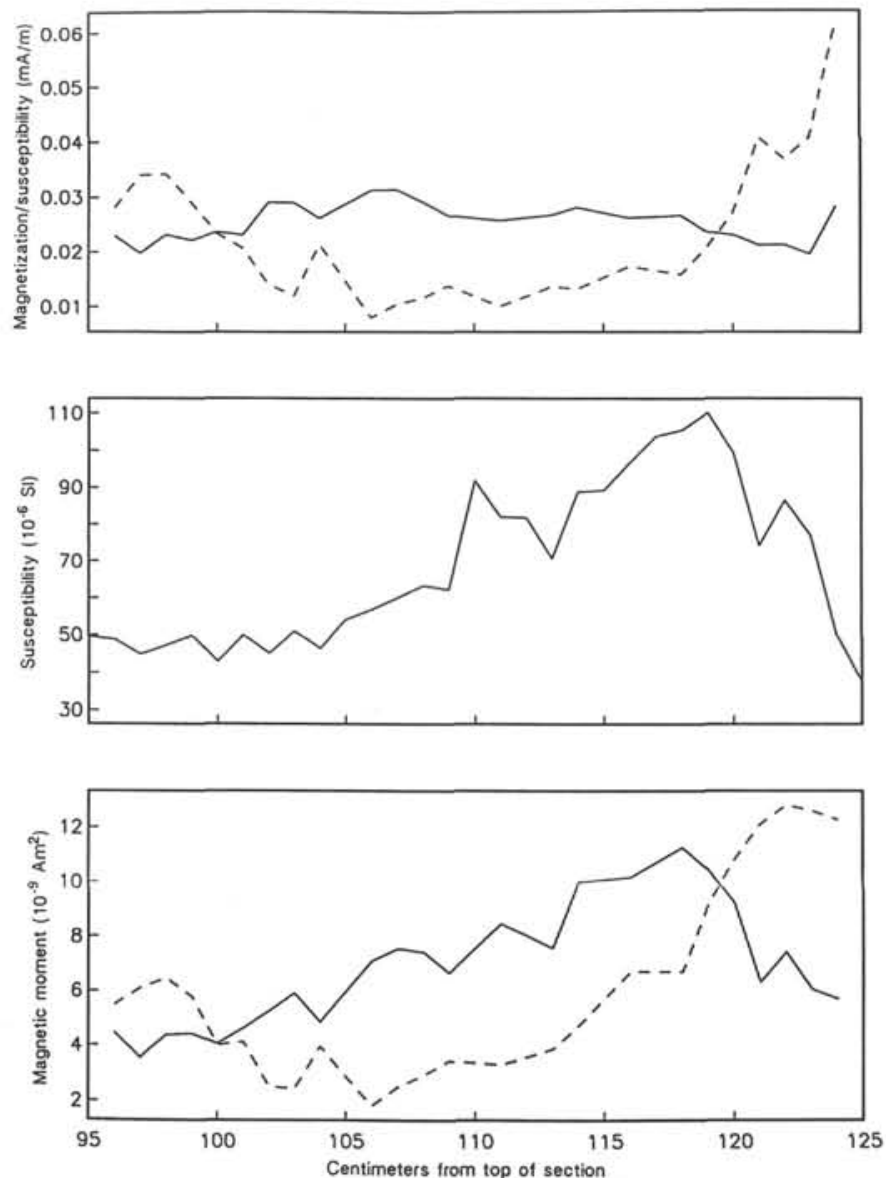

B

Lower onomalous zone
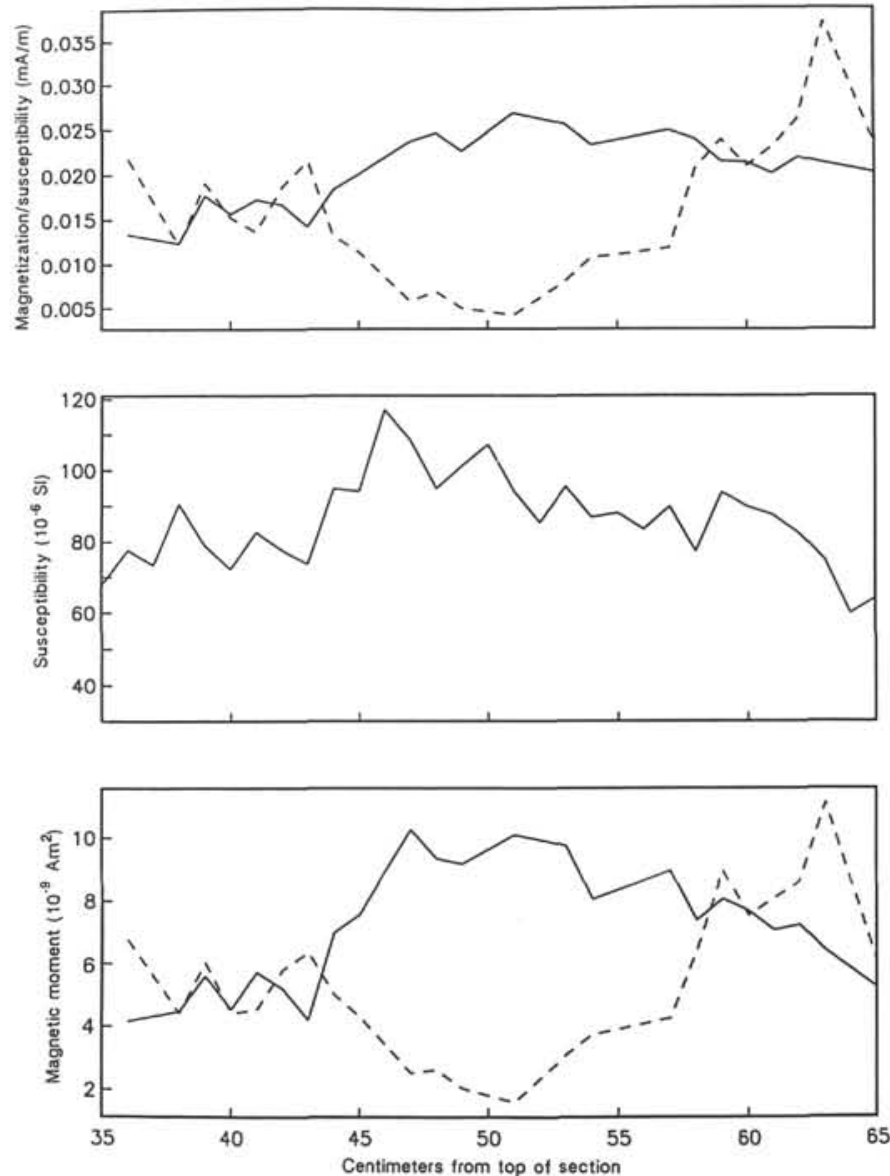

Figure 10. Changes in magnetic moment through the intermediate (A) and lower (B) anomalous zones. In the lower panel, the continuous (dashed) line describes the magnetic moment of the low-temperature normal polarity (high-temperature reversed polarity) component. The normalization of these curves by the susceptibility (middle panel) shows that the relative contribution of VRM acquisition remains constant throughout the anomalous zones (continuous line in the top panel). The normalized high-temperature component (dashed lines) could indicate that these intervals occurred in periods of low geomagnetic intensity. In the top panel, we show the change in magnetic polarity deduced from the continuous measurements at the NRM step. 
Cobb Mountoin sub-chron
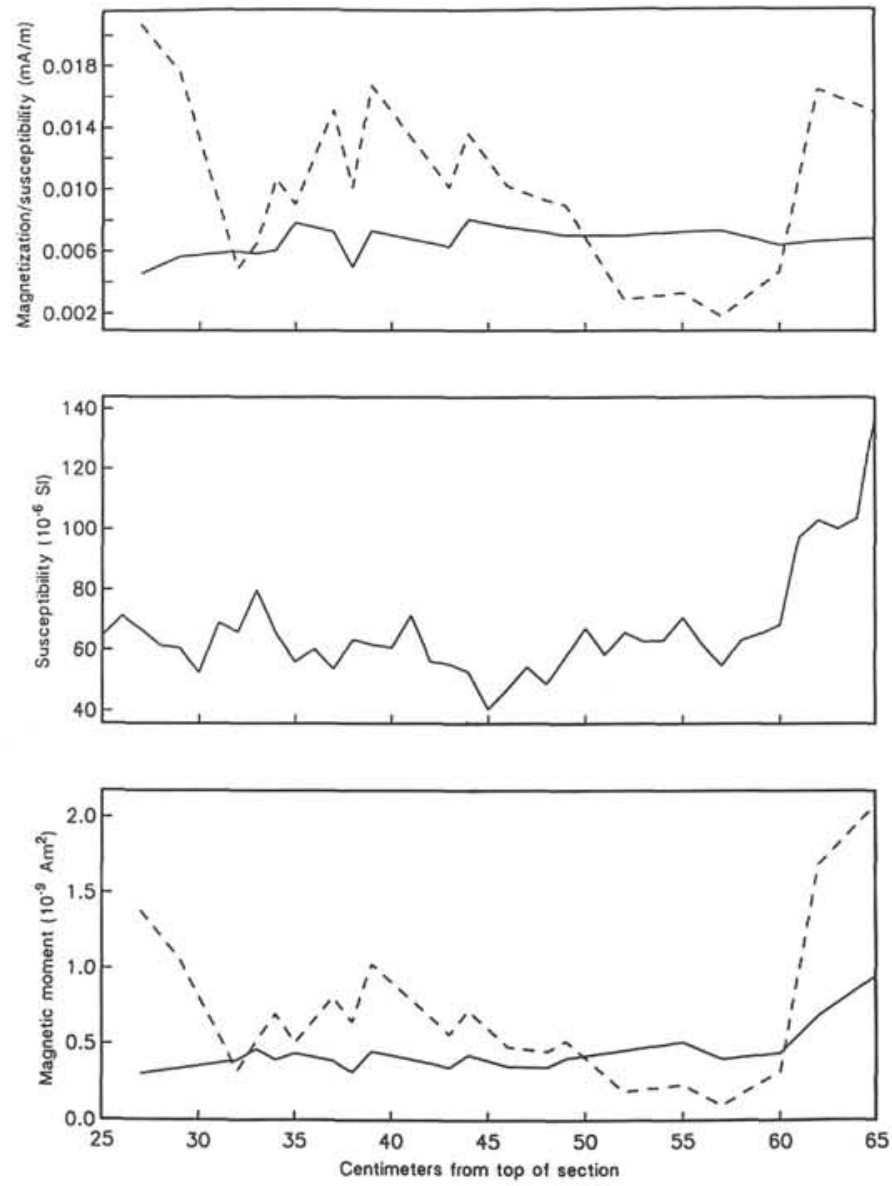

Figure 11. Changes in magnetic moment through the upper normal magnetic zone (Cobb Mountain Subchron). Same conventions as in Figure 10. 